\title{
PERILAKU DISIPLIN ANAK PADA PELAKSANAAN BELAJAR DARI RUMAH (BDR) DI RA AL-AKHYAR
}

\author{
Husnul Khatimah Yasin ${ }^{凶}$ \\ Pendidikan Guru Pendidikan Anak Usia Dini, Universitas Negeri Makassar
}

\begin{abstract}
:
This research study about the disciplinary behavior of children in the implementation of learning from home in RA Al-Akhyar. The subjects of this research is 14 children and 2 teachers in RA Al-Akhyar. The data was collected using observation, interview, and documentation. The data was analyzed by reduce data, presented data, and draw conclusion. The results of this study obtained that the disciplinary behaviour of children during the learning from home system implemented in RA Al-Akhyar is that students have developed as expected. This is proven by the achievement of six indicators of disciplinary behavior, namely : filling out the online attendance list on time, wearing uniforms during learning from home, praying in an orderly manner before starting lessons and after online learning during learning from home, trying to do the tasks that have been given during home study accompanied by parents, completing all tasks given by teachers during home study and collecting tasks on time given by teachers before online learning closes.
\end{abstract}

Keywords: Learning from home, disciplinary behavior, early childhood.

\begin{abstract}
Abstrak:
Penelitian ini mengkaji tentang perilaku disiplin anak pada pelaksanaan Belajar Dari Rumah (BDR) di RA Al-Akhyar. Subjek penelitian yang digunakan dalam penelitian ini adalah 14 orang anak dan 2 orang guru RA Al-Akhyar. Teknik pengumpulan data yang digunakan yaitu observasi, wawancara, dan dokumentasi. Teknik analisis data yang digunakan adalah reduksi data, menyajikan data dan menarik kesimpulan. Hasil penelitian ini diperoleh bahwa perilaku disiplin anak selama sistem Belajar Dari Rumah (BDR) dilaksanakan di RA Al-Akhyar adalah anak didik telah berkembang sesuai harapan. Hal ini terbukti dengan tercapainya dari enam indikator perilaku disiplin, yaitu : mengisi daftar hadir online tepat waktu, memakai pakaian rapi mengenakan seragam selama BDR, berdoa dengan tertib sebelum memulai pelajaran dan sesudah pembelajaran daring selama BDR, berusaha untuk mengerjakan tugas yang telah diberikan selama BDR dengan didampingi orangtua, menyelesaikan semua tugas yang diberikan oleh guru selama BDR berlangsung serta mengumpulkan tugas tepat waktu yang diberikan oleh guru sebelum pembelajaran online ditutup.
\end{abstract}

Kata Kunci: Media Lingkungan Sekitar, Minat Belajar, Anak Usia Dini 


\section{PENDAHULUAN}

Negara Indonesia saat ini dilanda oleh wabah virus corona atau biasa disebut dengan COVID-19. Penyebaran COVID-19 ini membuat banyak kegiatan publik beralih dengan pusat aktivitas utamanya berada di rumah. Situasi ini merupakan realitas baru, yang juga dialami di dunia pendidikan, serta membuat banyak sekolah terpaksa menghentikan proses pembelajaran tatap muka, utamanya terjadi pada pengajaran anak usia dini atau PAUD. Pendidikan Anak Usia Dini (PAUD) adalah jenjang pendidikan sebelum dilaksanakannya pendidikan dasar. PAUD merupakan masa yang tepat dalam upaya mendidik anak, yang ditujukan bagi anak sejak lahir hingga sampai usia enam tahun, dan dilakukan melalui pemberian rangsangan pendidikan untuk membantu pertumbuhan dan perkembangan jasmani dan rohani secara optimal. Hal ini berkaitan dengan pendapat Syamsuardi (2012, p. 60), bahwa masa usia dini adalah pendidikan fundamental dalam terbentuknya perkembangan dasar anak akan pengetahuan, sikap dan keterampilannnya.

Anak prasekolah berada pada masa lima tahun pertama yang disebut the golden age, atau masa emas perkembangan anak. Artinya adalah masa dimana anak usia dini pada masa itu anak tengah gemar mengksplorasi hal-hal yang mereka ingin tahu. Gardener (Winiarum, 2019) seorang tokoh pendidikan dan psikologi yang terkenal dengan teorinya tentang kecerdasan majemuk, juga menjelaskan bahwa pada lima tahun pertama, anak-anak selalu diwarnai dengan keberhasilan pada segala proses belajar. Dampak dari wabah COVID-19 ini hampir membuat seluruh sektor kehidupan masyarakat menurun. Aktivitas sosial dilarang dan ditunda sementara waktu, melemahnya ekonomi, pelayanan transportasi dikurangi dan diatur dengan ketat, pariwisata dan pusat perbelanjaan ditutup. Mendikbud menilai (Wijoyo dan Indrawan, 2020), yang paling banyak akan perubahan besar ada di dua sektor sosial, yaitu pendidikan dan kesehatan. Semenjak dikeluarkannya Surat Edaran No.4 tahun 2020 tentang pelaksanaan kebijakan pendidikan dalam masa darurat penyebaran Corona Virus Disease (COVID-19) tanggal 24 Maret 2020 oleh Menteri Pendidikan dan Kebudayaan RI, secara resmi proses pembelajaran pada semua pendidikan, termasuk PAUD melakukan proses pembelajaran dari rumah melalui sistem daring.

Kejadian wabah COVID-19 ini membuat semua pihak mulai guru, orangtua, dan murid harus siap menjalani kehidupan baru (new normal) dengan menggunakan teknologi informasi dan media elektronik agar proses pengajaran maupun pembelajaran dapat berlangsung dengan baik. Sesuai dengan pendapat Wijoyo dan Indrawan (2020, p. 211), yang dimana pendidik dan peserta didik pada waktu yang sama berada dalam jaringan internet dapat berinteraksi satu sama lain layaknya pembelajaran konvensional.

Banyak kegiatan terstruktur anak selama di sekolah dalam mendukung tingkat pencapaian perkembangan anak, menjadi terhambat dan membuat mereka terpaksa untuk belajar di rumah dikarenakan wabah virus ini. Winiarum (2019), menjelaskan bahwa proses belajar anak terutama proses kegiatan pembelajaran di sekolah merupakan salah satu cara dalam meningkatkan kemampuan aspek perkembangan anak. Guru yang sebagai pendidik selama anak Belajar Dari Rumah (BDR) harus mengubah strategi dalam belajar mengajarnya, termasuk dalam memberikan penilaian dari enam aspek perkembangan anak yang dimana enam aspek perkembangan tersebut adalah hal yang sangat penting untuk ditingkatkan kepada anak usia dini. Salah satu aspek perkembangan yang tidak kalah pentingnya untuk dinilai adalah social dan emosional, yang dimana juga termasuk dalam 
perkembangan karakter dan salah satu karakter yang harus dimiliki oleh anak adalah perilaku disiplin Maemonah (2012, p. 35). Dengan disiplin, anak dapat memperoleh batasan untuk memperbaiki tingkah lakunya yang salah. Untuk itulah, disiplin bertujuan agar anak dapat menerapkan perilaku disiplin melalui penanaman yang diajarkan tentang bagaimana berperilaku dengan cara yang sesuai dengan standar kelompok sosial, sesuai peran yang ditetapkan kelompok budaya masyarakat dimana anaknya berasal.

Selama masa pendemi, orangtua dan guru berupaya untuk bekerja sama dalam mewujudkan proses pembelajaran sesuai yang diharapkan termasuk membentuk perilaku disiplin anak (Kusmiati et al., 2021, p. 80). Perilaku disiplin tidak tumbuh dengan sendirinya, melainkan perlu kesadaran tersendiri, latihan kebiasaan, dan juga adanya hukuman. Selama masa pandemi COVID-19 stimulasi dalam pembentukan perilaku disiplin anak mendapat dukungan oleh guru di sekolah. Namun karena pemerintah Indonesia mengeluarkan peraturan untuk melaksanakan kegiatan belajar-mengajar melalui sistem online/daring atau bisa juga kita sebut sebagai Belajar Dari Rumah (BDR), guru pun mau tidak mau harus memberikan stimulasi untuk pembentukan perilaku disiplin anak selama BDR.

Berdasarkan studi awal yang dilakukan oleh peneliti, cara belajar dari anak didik RA Al-Akhyar selama di rumah wajib memakai seragam walaupun sepengetahuan anak dalam memakai seragam cuma dipakai saat pembelajaran secara konvensional. Saat mengerjakan tugas yang diberikan oleh guru, anak menjadi sangat bergantung kepada orangtuanya, tidak mau mengerjakan sendiri, walaupun memang anak usia dini butuh didampingi dalam mengerjakan sebuah tugas. Masalah yang lain adalah masih ada anak yang terlambat mengisi daftar hadir online yang diberikan oleh guru di grup Whatsapp dikarenakan terlambat bangun.

Jadi, banyak orangtua anak yang mengeluh dan menyebabkan mereka kebingungan dalam membantu anak mengerjakan tugas yang diberikan oleh gurunya. Hal ini sesuai dengan pendapat Mufaziah dan Fauziah (2021, h.104), dimana menurutnya kendala yang dialami oleh orangtua dipengaruhi oleh dua faktor, yaitu faktor internal dan eksternal. Dimana faktor internal adalah hal-hal kecakapan orangtua dalam mendidik anaknya untuk tetap disiplin selama masa pandemi. Kecakapan pada faktor ini jelas bahwa orangtua masih banyak yang belum memahami bagaimana mendidik anak dikala pandemi, terutama untuk anak usia dini.

\section{METODE PENELITIAN}

Jenis penelitian ini adalah penelitian kualitatif deskriptif. Penggunaan desain penelitian kualitatif deskriptif dalam penelitian ini dimaksudkan untuk mendeskripsikan dan menganalisis mengenai perilaku disiplin anak selama sistem belajar dari rumah dilaksanakan di tengah wabah COVID-19. Subjek penelitian adalah guru RA Al-Akhyar sebanyak dua orang dan anak didik umur (4-5 tahun) RA Al-Akhyar. Peneliti menggunakan teknik observasi sebagai pengumpul data. Sebagai subjek penelitian, anak didik sebanyak 14 orang (4-5 tahun) tersebut diharapkan mampu untuk memberikan informasi mengenai perkembangan perilaku disiplin anak selama Belajar Dari Rumah (BDR) dilaksanakan. Peneliti menggunakan lembar pedoman observasi, dengan mengamati langsung perilaku disiplin anak yang sesuai dengan enam indikator dari perilaku anak yang telah ditentukan. 
Pengumpulan data yang kedua adalah dengan menggunakan teknik wawancara. Peneliti mewawancarai secara langsung pihak guru RA Al-Akhyar dengan menggunakan lembar pedoman wawancara, dan pertanyaannya telah disusun terlebih dahulu. Diharapkan dengan mewawancarai guru secara langsung, dapat memberikan informasi mengenai bagaimana perkembangan anak didik selama mereka menjalankan BDR serta bagaimana proses sistem BDR ini dilaksanakan di sekolah RA Al-Akhyar. Dan pengumpulan data terakhir adalah dengan dokumentasi. Dokumentasi yang digunakan dalam penelitian ini adalah berupa foto-foto anak selama belajar dari rumah serta foto hasil wawancara peneliti dengan guru RA Al-Akhyar.

Teknik analisis data yang digunakan dalam penelitian ini adalah model Miles dan Huberman (Moloeng, 2010), dimana dalam melakukan aktivitas dalam analisis data kualitatif secara interaktif dan berlangsung secara terus menerus sampai tuntas, sehingga datanya sudah jenuh. Model teknik analisis data milik Miles dan Huberman ini meliputi tiga tahap, yakni reduksi data, display data, dan penarikan kesimpulan. Berikut penjelasan lebih lanjut mengenai analisis data ini adalah reduksi data, peneliti terlebih dahulu melakukan pengumpulan data kemudian dipilih dengan rinci dari hasil observasi, wawancara, dan dokumentasi. Misalnya saat wawancara dengan guru di RA Al-Akhyar, ada jawaban yang tidak sesuai dengan apa yang diharapkan dalam pedoman wawancara, maka jawaban itu tidak dipakai. Kemudian apabila jawaban dari guru di RA Al-Akhyar terlalu luas, maka akan diambil intinya saja; display data, peneliti menyajikan data berupa hasil observasi perilaku disiplin anak, wawancara guru mengenai perilaku disiplin anak selama BDR, kegiatan guru saat mengajar selama BDR, dan lain sebagainya, yang mencakup dari pembahasan mengenai perilaku disiplin dalam penelitian ini; dan menarik kesimpulan dan verifikasi data, tahap terakhir yang dilakukan oleh peneliti dengan memberi kesimpulan terhadap hasil penafsiran dan evaluasi yang mencakup pencarian makna data serta memberikan penjelasan. Data seperti observasi perilaku disiplin anak, hasil wawancara guru tentang perilaku disiplin anak, kegiatan guru saat mengajar selama BDR yang telah dikemukakan pada penyajian data diinterpretasikan kemudian dianalisis untuk memperoleh kesimpulan.

Teknik pemeriksaan keabsahan data dalam penelitian ini yaitu dengan menggunakan triangulasi. Menurut Moleong (2010), keabsahan data dalam penelitian kualitatif menggunakan triangulasi. Dalam penelitian ini, peneliti menggunakan dua jenis triangulasi yaitu triangulasi sumber dan triangulasi Teknik. Triangulasi sumber digunakan oleh peneliti untuk mengecek data yang diperoleh dari hasil wawancara guru dan hasil observasi selama mengamati perilaku disiplin anak. Sedangkan triangulasi teknik digunakan oleh peneliti setelah mendapatkan hasil wawancara yang kemudian dicek dengan hasil dari lembar observasi perilaku disiplin yang digunakan dan dokumentasi.

\section{HASIL DAN PEMBAHASAN}

Pelaksanaan Belajar Dari Rumah oleh RA Al-Akhyar dilakukan pada Minggu ketiga, bulan Juli 2020. Awalnya pihak sekolah melaksanakan BDR ini tiap hari dengan pembelajaran sistem online, akan tetapi ada sebagian orangtua yang 'menitipkan' anaknya di sekolah, sehingga pelaksanaan BDR dibagi menjadi dua, yaitu secara daring atau online dan secara secara luring. Pelaksanaan BDR secara daring/online dilakukan setiap hari Senin 
Kamis, dengan jadwal tiap kelas yang berbeda-beda. Pihak sekolah sengaja menetapkan peraturan ini, yakni peraturan jadwal daring/online secara bergiliran tiap kelas agar mengurangi perkumpulan dalam penyebaran COVID-19 yang sekarang melanda Negara Indonesia.

Adapun uraian kegiatan proses dari pelaksanaan pembelajaran selama BDR, sesuai hasil dari observasi dan wawancara peneliti dengan pihak-pihak sekolah, adalah guru menginfokan ke grup kelas pelaksanaan kelas daring/online akan dimulai. Pertama kali guru menanyakan kesiapan anak dan meminta untuk mengisi daftar hadir online. Sebelum pelaksanaan pembelajaran daring menggunakan metode daring berupa video call Whatsapp dengan batasan durasi waktu. Sebelum membaca Iqra, guru melakukan tanya jawab singkat tentang kabar anak selama pandemik, kemudian guru mengajak anak untuk berdoa terlebih dahulu sambil memperhatikan bagaimana sikap anak anak-anak dalam berdoa. Setelah anak membaca bacaan iqra, guru mengajak anak untuk menghafalkan satu surah pendek pilihan melalui aplikasi video call Whatsapp dan diperdengarkan langsung hafalan tersebut kepada guru dan anak lain.

Pelaksanaan kegiatan pembelajaran inti, guru menggunakan sebuah video pembelajaran yang telah dibagikan ke grup Whatsapp, kemudian orangtua anak didik yang akan membantu memutarkan video pembelajaran tersebut. Lembar kerjan yang sudah dibagikan masing-masing oleh guru kepada orangtua anak didik saat pembelajaran tatap muka dilakukan. Setelah waktu yang diberikan habis, guru akan melihat hasil kerja anak (dengan bukti foto) yang dikirim oleh orangtua, anak yang telah selesai diberikan tugas, guru akan menghubungi mereka satu-persatu. Guru mengajak anak yang dihubungi untuk menyanyikan lagu sesuai dengan sub tema di hari itu, selanjutnya guru mengulang kegiatan yang telah dilakukan anak dan menyampaikan pesan-pesan moral sebelum menutup hubungan/telepon. Guru meminta anak untuk berdoa sebelum menutup kelas daring/online. Terakhir, guru memberikan salam dan anak-anak menjawab.

Berdasarkan hasil observasi dan wawancara peneliti di lapangan, dapat diuraikan sebagai berikut tentang perilaku disiplin anak selama mereka belajar dari rumah: a) Anak tepat waktu mengisi daftar hadir online sebelum kegiatan pembelajaran dimulai Berdasarkan hasil observasi dan wawancara yang peneliti lakukan di RA Al-Akhyar, pada form daftar hadir online RA Al-Akhyar dimana dari 14 orang anak, empat orang anak diantaranya terlambat mengisi daftar hadir secara online dikarenakan mengikuti kondisi dari pekerjaan orangtua. Guru pun mengambil sikap dengan memperbolehkan anak untuk mengisi daftar hadir online dengan waktu yang disesuaikan dengan kesempatan orang tua dan anak, baik pada waktu sore atau malam. Adapun form daftar hadir online ini dibagikan dari jam 07.30 pagi, dengan cara guru membagikan link di grup Whatsaap, kemudian nanti orangtua tinggal membuka web tersebut; b) Anak berpakaian rapi mengenakan seragam sesuai aturan yang telah disepakati sebelum masuk ke pembelajaran daring. Berdasarkan hasil observasi dan wawancara yang peneliti lakukan di RA Al-Akhyar, dimana ada 10 dari 14 orang anak yang selama BDR dijalankan mereka tetap memakai seragam sekolahnya walaupun mereka belajar di rumah; c) Anak berdoa dengan tertib sebelum memulai pelajaran dan sesudah pembelajaran daring selama BDR. Berdasarkan hasil observasi dan wawancara yang peneliti lakukan di RA Al-Akhyar, semua anak didik dari 14 orang yang yang jadi subjek peneliti sangat tertib membaca doa harian (sebelum belajar, masuk rumah, 
dan lain-lain) dan dua surah pendek, baik itu sebelum pembelajaran maupun setelah pembelajaran dari rumah (daring/online) dimulai; d) Anak berusaha untuk mengerjakan tugas yang telah diberikan selama BDR dengan didampingi oleh orangtua. Berdasarkan hasil observasi dan wawancara yang peneliti lakukan di RA Al-Akhyar, 10 dari 14 orang anak selalu mengerjakan tugas yang diberikan selama BDR dilaksanakan. Selama mengerjakan tugas dari guru, tentu saja mereka didampingi oleh orangtua, yang sebagai pengganti guru di rumah (karena pandemi dan sistem BDR); e) Anak menyelesaikan semua tugas yang diberikan oleh guru selama BDR berlangsung. Berdasarkan hasil observasi dan wawancara yang peneliti lakukan di RA Al-Akhyar, 12 dari 14 orang anak dapat menyelesaikan semua tugas yang telah diberikan oleh guru selama BDR berlangsung. Semua tugas yang diselesaikan anak dikumpulkan menjadi satu dokumen dalam map masing-masing anak, yang dimana tugas tersebut merupakan lembar tugas yang dikerjakan selama seminggu yang telah diberikan oleh guru sebelumnya; dan f) Anak mengumpulkan tugas yang diberikan oleh guru tepat waktu sebelum pembelajaran daring-nya ditutup. Berdasarkan hasil observasi dan wawancara yang peneliti lakukan di RA Al-Akhyar, 10 dari 14 orang anak tepat waktu mengumpulkan tugas yang diberikan selama BDR. Tugas yang dikumpulkan ini berupa foto si anak yang telah selesai mengerjakan tugasnya, yang dimana tentu saja orangtua anak-anak yang membagikan foto tersebut ke grup Whatsapp.

Masa pandemi COVID-19 saat ini memberikan dampak dalam bidang apapun, termasuk pada bidang pendidikan. Salah satunya dalam bidang pendidikan anak usia dini, yang mengharuskan guru untuk melakukan pembelajaran dari rumah atau daring/online. Kebijakan baru new normal pemerintah Indonesia ini membuat guru-guru PAUD mengubah seluruh kegiatan pembelajaran konvensional menjadi daring/online, termasuk para guru di sekolah RA Al-Akhyar. Hal ini didukung dalam penelitian Wijoyo dan Indrawan (2020, p. 211), menyatakan kegiatan belajar mengajar yang biasanya dilakukan secara tatap muka langsung, dimana pendidik dan anak didik hadir secara fisik di ruangruang kelas dan tempat-tempat belajar, kini digantikan dengan kegiatan pembelajaran melalu media elektronik (e-learning).

Biasanya jika guru ingin menilai perkembangan anak, mereka akan melihat secara langsung pencapaian perkembangan dari si anak didik tersebut, apalagi dalam hal penilaian perkembangan karakter disiplin pada anak. Akan tetapi dikarenakan wabah COVID-19, para guru RA Al-Akhyar berusaha semaksimal mungkin untuk memberikan penilaian dari capaian perkembangan anak walaupun tidak secara langsung atau dalam melakukan penilaian. Jika dalam pembelajaran tatap muka (sebelum wabah) anak didik RA Al-Akhyar disiplin dalam menaati aturan, baik itu memakai seragam, datang tepat waktu, dan lain sebagainya, maka sama juga dengan halnya saat pembelajaran Belajar Dari Rumah (BDR), akan tetapi dengan konsep yang berbeda.

Terkait di atas, sesuai dengan pendapat dari Wulandari dan Purwanta (2020, p. 452), dimana proses pembelajaan tatap muka lebih memudahkan guru untuk langsung menilai pencapaian perkembangan pada anak, karena anak-anak yang belajar secara langsung di dalam kelas memiliki lebih banyak kesempatan utuk memilih berbagai kegiatan, juga dapat melakukan interaksi secara langsung dengan guru serta teman-temanya, sehingga hal tersebut nanti dapat menstimulasi pencapaian dalam perkembangan anak, terutama perkembangan sosial-emosionalnya. 
Indikator perilaku disiplin dapat digunakan sebagai acuan untuk mengetahui sikap disiplin anak. Indikator perilaku disiplin ini secara umum ditetapkan oleh Kemendiknas (2010), yang dimana indikator dari sikap disiplin adalah: a) membiasakan hadir tepat waktu, b) membiasakan mematuhi aturan dan c) menggunakan pakaian sesuai dengan ketentuan. Dimana berdasarkan hasil observasi yang telah dilakukan di RA Al-Akhyar, anak telah membiasakan hadir tepat waktu selama sistem Belajar Dari Rumah (BDR) dilaksanakan yaitu dengan mengisi daftar hadir online, anak mematuhi aturan-aturan yang ada di sekolah, seperti berpakaian rapi mengenakan seragam selama BDR, membaca doa sebelum dan sesudah pembelajaran selama anak-anak belajar di rumah/daring, menyelesaikan dan mengumpulkan semua tugas-tugas yang diberikan oleh guru selama sistem Belajar Dari Rumah (BDR) dilaksanakan.

Perilaku disiplin dapat dijadikan sebagai alat untuk mengukur sejauh mana karakter anak, dengan melakukan pembiasan-pembiasaan sedari dini atau dimasa usia golden age. Dengan mengajarkan perilaku disiplin sejak dini, kelak saat dewasa nanti anak akan lebih mengontrol dirinya dari tingkah laku yang pantas dan tidak pantas, terkontrol dan bertanggung jawab. Sesuai dengan pendapat dari Koyimah dan Kusumangnityas (2017, p. 49), bahwa disiplin adalah sikap seseorang yang menunjukkan ketaatan atau kepatuhan terhadap peraturan atau tata tertib yang telah ada dan dilakukan dengan kesadaran diri dan dalam menanamkan disiplin pada anak, dibutuhkan peran orangtua. Juga pendapat dari Lukitasari (2017, p. 232), bahwa pembentukan perilaku akan sejak dini mampu memengaruhi perkembangan anak di masa mendatang. Perilaku dan sikap yang terbentuk pada anak akan dibawa seumur hidup. Oleh karena itu, hendaknya orang dewasa dapat menanamkan perilaku kedisiplinan sejak dini, agar anak dapat berperilaku dengan baik dalam lingkungannya, baik itu di lingkungan keluarganya maupun di lingkungan masyarakat di masa mendatang.

Berkaitan dari pendapat ahli di atas dan berdasarkan hasil observasi serta wawancara dari guru dapat dijelaskan bahwa perilaku disiplin pada anak didik RA Al-Akhyar dapat dilihat dari diri mereka yang tetap mematuhi aturan dan tata tertib sekolah selama mereka belajar di rumah. Seperti perilaku disiplin tetap memakai pakaian seragam walaupun kondisi belajar anak-anak berada di rumah. Anak didik RA Al-Akhyar selama sistem Belajar Dari Rumah (BDR) dilaksanakan, mereka berusaha mengerjakan dan menyelesaikan tugas dari guru dengan didampingi oleh orangtua tentu saja. Hal ini berkaitan dengan manfaat mengenai perilaku disiplin menurut Al-Faruq (2012) salah satu dari manfaat disiplin adalah membantu anak menjadi matang pribadinya dan mengubah sifat-sifat ketergantungan yang ada pada anak menjadi sifat kemandirian, jadi anak mampu melaksanakan tanggung jawab yang ada pada dirinya, seperti mengerjakan tugas-tugas dari guru selama BDR, dan tidak meninggalkan pekerjaan atau tugas-tugas tersebut.

Dengan keadan wabah COVID-19 ini, guru sebagai pendidik dan pembimbing dituntut untuk tetap terus mendidik anak didik. Selama sistem Belajar Dari Rumah (BDR) dilaksanakan, para guru di RA Al-Akhyar semaksimal mungkin untuk tetap menjalankan tugasnya dalam mendidik dan membimbing di sekolah (secara daring/online). Dapat dilihat saat para guru berupaya untuk memberikan varian tugas atau aktivitas yang beragam dan kreatif yang dapat dikerjakan bersama orangtua di rumah, seperti memberikan tugas pada anak untuk bermain peran bersama orangtuanya saat sentra "bermain peran". Yang dimana 
salah satu bermain peran ini, sang anak membantu ibunya selama mereka belajar di rumah, dengan membantu ibu membersihkan rumah, merapikan tempat tidurnya, dan lain sebagainya. Dalam hal ini, menurut Siregar (2020) diperlukan kerjasama antara orangtua dan guru dalam membangun sikap disiplin anak selama mereka menjalankan pembelajaran dari rumah.

Salah satu upaya yang dapat dilakukan oleh guru selama anak didik RA Al-Akhyar belajar di rumah saja adalah dengan memberikan varian aktivitas yang dapat dilakukan anak bersama orangtua yang lebih menekankan pada karakter, terutama karakter disiplin. Di atas telah dijelaskan bahwa salah satu upaya guru dalam memberikan aktivitas yang dapat mengembangkan karakter disiplin pada anak adalah dengan memberikan tugas "bermain peran" membantu ibu selama belajar di rumah. Hal ini dapat membantu anak untuk mengembangkan karakter disiplinnya. Ini juga dilakukan agar anak didik tidak 'lupa' supaya tetap menjaga sikap disiplinnya selama mereka belajar dari rumah.

Temuan lapangan ini berhubungan dengan salah satu teori dari Yatun, dkk (2020, pp. 4-5), dimana hasil penelitiannya adalah nilai-nila karakter anak berupa disiplin menjadi nilai utama bagi perilaku anak dan setiap manusia. Kerjasama antara orangtua dan guru dalam menanamkan sikap disiplin anak usia dini pada pembelajaran daring/online selama Belajar Dari Rumah (BDR) dapat diartikan sangat baik, bahkan memenuhi semua indikator item tertentu. Hal ini menunjukkan bahwa baik orangtua maupun guru sama-sama memiliki pandangan bahwa sikap disiplin pada anak harus tetap ditanamkan atau bahkan diwujudkan dalam aktivitas anak sehari-hari, walaupun pembelajaran mereka berada di rumah.

\section{SIMPULAN}

Hasil penelitian ini diperoleh bahwa perilaku disiplin anak selama sistem Belajar Dari Rumah (BDR) dilaksanakan di RA Al-Akhyar adalah anak didik telah berkembang yang ditunjukkan oleh dengan tercapainya dari enam indikator perilaku disiplin, yaitu: mengisi daftar hadir online tepat waktu, memakai pakaian rapi mengenakan seragam selama BDR, berdoa dengan tertib sebelum memulai pelajaran dan sesudah pembelajaran daring selama BDR, berusaha untuk mengerjakan tugas yang telah diberikan selama BDR dengan didampingi orangtua, menyelesaikan semua tugas yang diberikan oleh guru selama BDR berlangsung serta mengumpulkan tugas tepat waktu yang diberikan oleh guru sebelum pembelajaran online ditutup.

\section{DAFTAR PUSTAKA}

Al-Faruq, Assadullah. 2012. Kiat-Kiat Islami Mendidik Akhlak Remaja. Jakarta: PT. Elex Media Komputindo.

Belawati, Tian. 2003. Penerapan E-learning dalam Pendidikan Jarak Jauh di Indonesia. Jakarta: Universitas Terbuka.

Familia, T.P. 2007. Mempertimbangkan Hukuman Pada Anak. Kanisius: Yogyakarta.

Gustina, Fatma. 2017. Pengaruh Model Pembelajaran Maria Montessori Terhadap Pengembangan Kedisiplinan Anak Usia 4-5 Tahun di TK Islam Ibnu Qoyyim Kec.Medan Selayang Setia Budi. Skripsi (Tidak Diterbitkan). Fakultas Ilmu Terbiyah dan Keguruan. Universitas Islam Negeri: Medan. 
60| TEMATIK, Juni 2021, Volume 7, Nomor 1, Halaman 52-61

Herliandry, D.L, dkk. 2020. Pembelajaran Pada Masa Pandemi COVID-19. Jurnal Teknologi Pendidikan. Vol.22, No.1, hl.65-70

Imron, Ali. 2011. Manajemen Peserta Didik Berbasis Sekolah. Jakarta: Bumi Aksara.

Indrakusuma, A.H., dan Putri A.R. 2016. E-learning: Teori dan Desain. Program Studi Pendidikan Teknologi Informasi: STKIP PGRI Tulungagung.

Kurniati, E., dkk. 2020. Analisis Peran Orangtua dalam Mendampingi Anak di Pandemi Covid-19. Jurnal Obsesi: Jurnal Pendidikan Anak Usia Dini. Vol.5, Issue 1 (2021), hl.241-256.

Kementrian Pendidikan Nasional. 2010. Pengembangan Pendidikan Budaya dan Karakter Bangsa. Jakarta: Kementrian Pendidikan Nasional.

Koyimah, S., \& Kusumaningtyas, N. (2017). PENANAMAN SIKAP DISIPLIN ANAK MELALUI PROGRAM PARENTING DI PAUD TUNAS JAYA KECAMATAN SEMARANG UTARA. PAUDIA: JURNAL PENELITIAN DALAM BIDANG PENDIDIKAN ANAK USIA DINI, 6(1), 46-63. https://doi.org/10.26877/paudia.v6i1.1865

Kusmiati, E., Yunia Sari, D., Mutiara, S., Dasar, S., Garut, S., \& Islam Nusantara Bandung, U. (2021). POLA ASUH ORANG TUA DALAM MEMBENTUK DISIPLIN ANAK DI MASA PANDEMI. PERNIK Jurnal PAUD, 4(2), 78-93.

Larimore, R.A. 2020. Preschool Science Educstion: A Vision for The Future. Journal Early Childhood Education.

Lukitasari, Suci. 2017. Deskripsi Kedisiplinan Anak Usia 5-6 Tahun di KB/TK Pedagogia. Jurnal Pendidikan Anak Usia Dini. Edisi 03 Tahun ke-6, hl.231-240.

Maemonah. (2012). Aspek-aspek dalam pendidikan karakter. Forum Tarbiyah, 10(9), 31.

Mehta, Puja., dkk. 2020. COVID-19: Consider Cytokine Storm Syndromes and Immunosuppression. Journal Elsevier Public Health Emergency Collection, PMC7270045.

Mulyasa, E. 2006. Kurikulum Tingkat Satuan Pendidikan. Bandung: PT Remaja Rosdakarya.

Munir. 2009. Pembelajaran Jarak Jauh Berbasis Teknologi Informasi dan Komunikasi. Bandung: Alfabeta.

Moenir, H.A.S. 2010. Manajemen Pelayanan Umum di Indonesia. Jakarta: Bumi Aksara.

Moleong, Lexy.J. 2010. Metode Penelitian Kualitatif Edisi Revisi. Jakarta: PT. Remaja Rosdakarya.

Musfiqon. 2012. Pengembangan Media dan Sumber Pembelajaran. Jakarta: PT. Prestasi Pustakaraya.

Nurdin, I.R. 2017. Penerapan Sistem Pembelajaran Jarak Jauh Berbasis Massive Open Online Course (MOOC) di Universitas Ciputra Entrepreunership Online (UCEO). Skripsi. Fakultas Ilmu Pendidikan. Universitas Negeri Semarang: Semarang.

Ningrum, D.K. 2018. Upaya Meningkatkan Perilaku Disiplin Anak Usia 4-5 Tahun Melalui Permainan Ular Tangga Bercerita. Skripsi. Fakultas Ilmu Pendidikan. Universitas Ngeri Jakarta: Jakarta. 
Pedoman Pelaksanaan Belajar Dari Rumah Selama Darurat Bencana COVID-19 di Indonesia. 2020. Kementerian Pendidikan dan Kebudayaan Republik Indonesia.

Pedoman Pengembangan Pembiasaan di Taman Kanak-kanak. 2007. Jakarta: Departemen Pendidikan Nasional

Rudi, S., dan Riyana, C. 2007. Media Pembelajaran. Bandung: CV.Wacana Prima.

Rompas, R., dkk. 2018. Hubungan Peran Orangtua dengan Perilaku Hidup Bersih dan Sehat Anak Usia Sekolah di SD Inpres Talikuran Kecamatan Kawangkoan Utara. e-Journal Keperawatan. Vol.6, Nomor 1, Mei 2018.

Sadiman, Arief, dkk. 2014. Media Pendidikan : Pengertian, Pengembangan, dan Pemanfaatannya. Jakarta : PT Rajagrafindo Persada

Siregar, Julinda. (2020). Kerjasama Orangtua dan Guru dalam Mengelola Strategi Pembelajaran Home Learning Masa Pandemi Covid-19 di PAUD Kasih Efrata Jatiasih Bekasi. Jurnal DInamika Pendidikan, 13(3), 245-25

Sugandi, Achmad., dkk. 2004. Teori Pembelajaran. Semarang: UPT MKK UNNES.

Sukmadinata, Nana.S. 2011. Metode Penelitian Pendidikan. Bandung: PT.Rosdakarya.

Suryadi. 2007. Cara Efektif Memahami Perilaku Anak Usia Dini. Jakarta: EDSA Mahkota.

Syamsuardi. (2012). Penggunaan Alat Permainan Edukatif (APE) di Taman Kanak-Kanak PAUD Polewali Kecamatan Tanete Riattang Barat Kabupaten Bone. Jurnal Publikasi Pendidikan, II(1), 59-67.

Wiyani, N. A. 2013. Bina karakter anak usia dini. Yogyakarta: Ar-ruzz Media

Wijoyo. H, I. I. (2020). Model Pembelajaran Menyongsong New Era Normal Pada Lembaga Paud Di Riau *Hadion Wijoyo **Irjus Indrawan *STMIK Dharmapala Riau **Universitas Islam Indragiri Surel: *Hadion. Jurnal Sekolah PGSD FIP UNIMED, 4, 205-212.

Winiarum, Fatonah. 2019. 25+ Ide Kreatif Membuat Mainan Edukatif untuk Anak. Yogyakarta: Trans Ide Publishing

Wulandari, H., \& Purwanta, E. (2020). Pencapaian Perkembangan Anak Usia Dini di Taman Kanak-kanak selama Pembelajaran Daring di Masa Pandemi Covid-19. Jurnal Obsesi: Jurnal Pendidikan Anak Usia Dini, 5(1), 452-462. https://doi.org/10.31004/obsesi.v5i1.626

Yatun, S., \& Salehudin, M. (2020). Persepsi Orang Tua dan Guru dalam Menanamkan Disiplin Anak Usia Dini pada Pembelajaran Online. Jurnal Ilmiah Potensia, 6(1), 110. https://ejournal.unib.ac.id/index.php/potensia

Zahrok, S., dan Suarmini, N.W. 2018. Peran Perempuan dalam Keluarga. IPTEK Journal of Proceedings Series. 